\author{
Ks. Józef Zabielski \\ Uniwersytet w Białymstoku
}

\title{
NORMATYWNY CHARAKTER NOWEGO PORZĄDKU ŚWIATOWEGO
}

\section{NORMATIVE CHARACTER OF NEW WORLD ORDER}

The nature of being human constitutes the primary source of obligations and norms of human actions. In the religious and theological realm they are perceived as an expression of Cod's will, and the human mind expresses them in the form of normative laws. To give an example, life in itself is a value of exceptional normative dimension, but it is the situation of a threat to life that enhances this norm in a special way. Transplanting this way of thinking to the contemporary world and the rules governing it, we wish to discuss in this work the question of moral norms which are contained in the developing new world order. Our objective is to show that the fact and the existential meaning of the new order of contemporary world constitute an ethical challenge for contemporary people. Discussing this problem, we first spoke about the crucial elements of this order as the sources of the norm (part 1), and then we showed the subjective and formal dimension of this obligation (part 2).

Źródła powinności i norm ludzkiego działania zasadniczo upatrujemy w naturze danego bytu, w których w porządku religijno-teologicznym rozpoznajemy też wolę Boga, oraz w akcie ludzkiego rozumu stanowiącego prawo. Analizując naturę danej rzeczywistości jako fundament normatywu moralnego zauważamy, że niekiedy szczególne postacie i formy bytowania zwłaszcza ważne w sensie egzystencjalnym - wykazuja wyjątkowy charakter normatywny. Przykładowo, życie samo w sobie jest wartością i źródłem normatywu jego zachowania, ale fakt zagrożenia życia, ów normatyw jeszcze eksponuje i czyni go bardziej naglącym. To rozumowanie przenosimy na fakt i problem sytuacji współczesnego świata i jego funkcjonowania. W niniejszej refleksji chcemy rozwinąc zagadnienie normatywu moralnego, jaki zawiera się w tym nowym porządku współczesnego świata. Innymi słowy: chcemy wykazać, że fakt i egzystencjalne znaczenie nowego porządku 
w świecie stanowi etyczne wyzwanie dla współczesnych ludzi. Rozwijając ten problem najpierw zwrócimy uwagę na istotne elementy tego porządku jako źródła owego imperatywu (I), aby następnie ukazać podmiotowoformalny wymiar tej powinności (II).

\section{Charakterystyczne wyznaczniki nowego porządku jako źró- dła normatywu}

Uwzględniając hierarchię bytów w kształtowaniu porządku rzeczywistości świata, najpierw należy odnieść się do Transcendencji - Boga, rozumianego jako początek i kres człowieka i świata. W dzisiejszej rzeczywistości łatwo zauważyć, że jest coraz więcej ludzi, których Transcendencja - Bóg, jak też oparty na tym moralny porządek, przestają interesować. Wielu współczesnych nam ludzi w rozeznawaniu sensu świata i swego życia, nie odnosi się do Boga, w swoich zaś decyzjach idziałaniu nie uwzględnia pochodzacych stąd norm etycznych. Postawę taką wielokrotnie podzielają nawet ci, którzy uznaja [deklaruja] siebie wierzącymi, choć w praktyce zachowują w tym zakresie obojętność. Bywają też tacy, którzy wiarę i odniesienie do Boga w życiu moralnym traktują wyłącznie jako rzeczywistość prywatna, w życiu publicznym zaś chcą być traktowani jako neutralni, dla których Bóg nie stanowi problemu egzystencjalnego ${ }^{1}$. Takie odniesienie do Boga i religii jest charakterystyczne dla mniejszych lub większych społeczności i to we wszystkich częściach świata, choć w różnym wymiarze. Jan Paweł II takie życie ,jakby Bóg nie istniał” określił jako „część ducha europejskiego. Część europejskiej nowożytnej tradycji”'. Opisując zaś życie religijne współczesnej Ameryki kard. Juan Sandoval Iñiquez podkreśla, że społeczności tego kontynentu charakteryzuje coraz powszechniejszy „styl życia obojętny na Boga i tendencja do usuwania religii i zasad moralnych na ubocze życia społeczne-

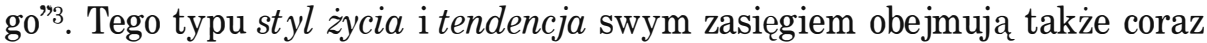
więcej dziedzin ludzkiego życia i jego form. „W sferze kultury ateistyczny laicyzm zyskuje często przewagę $\mathrm{w}$ środowiskach intelektualnych i twórczych. Niewielu jest katolików pracujących na uniwersytetach, wśród ludzi kultury i sztuki, a także w środkach społecznego przekazu. W sferze

1 Por. K. Nientiedt, Kommen die Heiden?, „Herder Korrespondenz” 46(1992), nr 8, s. $345-346$.

2 Jan Paweł II, Homilia, Warszawa, 09.06.1991 r., w: Czwarta pielgrzymka Jana Pawła II do Polski, Poznań-Warszawa 1991, s. 223.

${ }^{3}$ Kard. J. S. Iñiquez, Relatio ante disceptionem [Spotkanie z Jezusem Chrystusem żywym droga do nawrócenia...], „L'Osservatore Romano” [pol.] 19(1998), nr 2, s. 37. Por. A. Greelcy, Religion Not Dying Out Around the World, „Originis” 23/4(1993), s. 49-58. 
wychowania próbuje się często sprowadzać wychowanie wyłącznie do nauczania, w którym nie ma miejsca na wartości transcendentne"4.

Powszechność tego rodzaju postaw w zakresie myśli i praktyki życia postrzegana jest jako charakterystyczny fenomen współczesności, „znak czasu"5, szczególny wymiar nowoczesności ${ }^{6}$, jak też przyczyna zachwiania ładu moralnego ${ }^{7}$. Tego rodzaju sytuacja stanowi wielkie wyzwanie, które Jan Paweł II, u progu trzeciego tysiąclecia chrześcijaństwa, wyraził w dramatycznym pytaniu: „Czy może [...] przemilczeć zjawisko obojętności religijnej, która sprawia, że wielu współczesnych ludzi żyje dziś tak, jak gdyby Bóg nie istniał, albo zadowala się mglistą religijnością, niezdolną sprostać problemowi prawdy ani obowiązkowi zachowania spójności między życiem i wiara?" ści, wyrażające się w przekonaniu, że postawy zobojętnienia religijnomoralnego rzeczywiście „nie można przemilczeć”. Ten imperatyw swe najgłębsze podstawy ma w tym, że „Bogu objawiającemu się należy się posłuszeństwo wiary" (por. Rz 16, 26; Rz 1,5; 1 Kor 10, 5-6) ${ }^{9}$. Uświadomienie sobie owej powinności człowieka oraz zestawienie tego z fenomenem religijno-moralnej obojętności, ukazuje istotę i moc wiążącą owego normatywu. Uwzględniając przy tym wielorakie skutki takiej postawy, w postaci szeregu ograniczeń, form zubożenia osoby ludzkiej i jej ziemskiego bytowania, Jan Paweł II podkreśla, że „zobojętnienie religijne i zupełny brak praktycznego odniesienia do Boga nawet w obliczu najpoważniejszych problemów życiowych sa zjawiskiem nie mniej niepokojącym i destrukcyjnym niż jawny ateizm"10. Moralny imperatyw zawiera się w samej istocie religijno -moralnego zobojętnienia, świadomość zaś jego skutków tylko wzmacnia poczucie owej powinności i wskazuje płaszczyzny bardziej szczegółowych zobowiązań w tym względzie.

4 Tamże. Por. J. Zabielski, Normatywny charakter wspótczesnej niewiary, „Studia Theologica Varsaviensia” 387(2000), nr 1, s.140-141.

5 Por. J. Zabielski, Indyferentyzm religijno-moralny jako „znak czasu”, w: Ad libertatem in veritate, red. P. Morciniec, Opole 1996, s. 503-520; P. Colin, L'indifférence religieuse. Disrurs anciens, questions nouvelle, „Etudes” 1985, nr 3, s. 390-402.

6 Por. P. Valadier, Société moderne et indifférence religieuse, „Catéchese” 1988, nr 110111, s. 63-75; P. Henrici, Die Modernität und das Christentum, „Communio" [niem.] 19(1990), nr 4, s. 289-295.

7 Por. H. Hemminger, Religiöse Angebote dienen als zusätzliche Dekorationen des Lebens, „Herder Korrespondenz” 47(1993), nr 7, s. 344-347; U. Ruh, Glaube als Kulturfaktor, „Herder Korrespondenz” 48(1994), nr 1, s. 1-2.

8 Jan Paweł II, List Apostolski Tertio millennio adveniente, 36. Por. H. Waldenfels, Das Christentum und die Kulturen, „Stimmen der Zeit” 116(1991), t. 209, s. 291-299.

${ }^{9}$ Por. Sobór Watykański II, Konstytucja Dei Verbum, 5.

10 Jan Paweł II, Adhortacja Apostolska Christifideles laici, 34. 
Drugim charakterystycznym wyznacznikiem nowego porządku świata, a tym samym normatywnym wyzwaniem, jest odniesienie do prawdy. Prawie powszechnie przyjmuje się, że do największych zagrożeń współczesności należy relatywizacja prawdy. Szerzący się liberalizm nie uznaje prawdy uniwersalnej i absolutnej, kwestionując zaś autonomię prawdy, absolutny priorytet przyznaje wolności. W tej sytuacji człowiek nie tyle winien podlegać prawdzie, co ma prawdę konstytuować, jest pojmowany nie jako sługa prawdy, lecz jako jej kreator. Na płaszczyźnie poznawczej objawia się to tym, że akty ludzkiego poznania „tworza” znaczenie danej rzeczywistości, co w konsekwencji zmienia kryteria prawdziwości. To zaś sprawia, że prawdę uważa się za wyraz życia podmiotu, przejaw jego osobowości, a nie zaś za sens bytu w sobie samym. Prawda została też zdetronizowana jako wartość najwyższa, przestała być uważana za wartość, której się służy i która stanowi miarę ludzkich działań ${ }^{11}$.

Tak zniekształcone rozumienie prawdy, która staje się ideologia, ma swe tragiczne wprost konsekwencje w odniesieniu do pojmowania i traktowania wartości bytu osobowego, zarówno jednostki, jak i społeczności. Człowiek jest rozumiany jako „miejsce” potrzeb i doznań, dość często sztucznie rozdmuchiwanych. Taki człowiek jawi się jako istota bez korzeni i celu, bez etosu, który może myśleć i postępować jak mu się podoba. Ten kryzys świadomości przyjmuje niekiedy postać dekadencji, która D. Bonhoeffer tak charakteryzuje: „Skoro nie ma nic trwałego, zanika fundament życia historii, czyli zawierzenie w każdej postaci. Ponieważ nie pokłada się zaufania w prawdzie, zastępuje się ją wybiegami propagandy. Przy braku zaufania w sprawiedliwość ogłasza się słusznym to, co za takie się uznaje [...]. Taki jest stan naszych czasów; czasów faktycznej dekadencji”12.

Jan Paweł II taką postawę określa jako „powszechną utratę poczucia transcendentnego sensu ludzkiej egzystencji oraz zagubienie na polu etyki, obejmujace nawet tak fundamentalne wartości, jak szacunek dla życia i dla rodziny”13. To „zagubienie na polu etyki” przejawia się także w zniekształceniu rozumienia i przeżywania wolności osoby oraz w różnych formach zagrożenia życia człowieka. W imię wynaturzonej wolności współczesny człowiek często domaga się arbitralnego decydowania o wartości i godności drugiego oraz jego istnieniu. Jakże często odrzuca się dziś prawdę, że „fundamentalną potrzebą antropologiczną nie jest potrzeba wolności, lecz po-

11 Por. A. Siemianowski, Człowiek i prawda, Poznań 1986, s. 11-12; P. Nitecki, Kościót $w$ świecie, „Życie”, 13-14.11.1999 r., s. 21; D. von Hildebrand, Gesammelte Werke, t. 7 [Idolkult und Gotteskult], Regensburg 1974, s. 312-337: J. Zabielski, Wspótczesny indyferentyzm religijny. Studium teologicznomoralne, Białystok 1999, s. 135-149.

12 D. Bonhoeffer, Etica, red. E. Bethage, Mediolan 1969, s. 91.

13 Jan Paweł II, List Apostolski Tertio millennio adveniente, 36. 
trzeba sensu, tożsamości, uznania"14. W konsekwencji lekceważy się potrzebę odnalezienia w sobie i w innych sensu, dojścia do poznania, kim jesteśmy, poczucia bycia akceptowanym przez drugiego. Człowiek zaś winien przede wszystkim pytać, kim jest i starać się dawać odpowiedź, odwołując się do tego, co jest dla niego najważniejsze. To bowiem przynosi człowiekowi spokój i poczucie spełnienia, bardziej niż sama zabsolutyzowana i abstrakcyjna rewindykacja wolności wyboru. „Do życia pełnego i satysfakcjonującego - podkreśla R. Dahrendorf - ludzie potrzebują czegoś więcej niż praw i pieniędzy. Potrzebuja miar, które nadałyby sens ich życiu, orientacyjnych znaków na drodze"15. Stąd też konieczne jest podjęcie odpowiednio pogłębionej refleksji o koncepcji wolności, uwzględniającej zwłaszcza sens istnienia człowieka oraz inne wrażliwe stany życia i cywilizacji. Ta refleksja i dyskusja z zachodnią kultura winna prowadzić do nowej cywilizacji, gdzie wolność nie będzie pojmowana jako jedyna i największa wartość, której wszystkie inne sa podporządkowane. W nowej cywilizacji poszczególne wartości winny zachować swą ważność i być jednoznacznie oddzielone od swych zniekształceń, żeby móc wyznaczać drogę do lepszej struktury życia publicznego. Taka potrzeba - konieczność przejścia do nowej formy cywilizacji jest kategoria obiektywna, zakorzeniona w ludzkiej potrzebie ratowania wartości i godności osoby oraz dążenia do lepszego życia ${ }^{16}$. Stąd też prawda o wartości i godności człowieka oraz właściwościach osoby ludzkiej winna wzbudzać „żywy i poważny odzew w sercu każdego człowieka, tak wierzącego, jak i niewierzą cego, ponieważ przerastając nieskończenie jego oczekiwania, zarazem w zadziwiający sposób współbrzmi z nimi. Mimo wszelkich trudności i niepewności każdy człowiek szczerze otwarty na prawdę i dobro może dzięki światłu rozumu i pod wpływem tajemniczego działania łaski rozpoznać, [...] że każda ludzka istota ma prawo oczekiwać absolutnego poszanowania tego swego podstawowego dobra"17.

Ten antropocentryzm oraz zniekształcona wolność stają się szczególnym wyzwaniem współczesności, gdyż kształtuja niebezpieczne odniesienie człowieka do normy i prawa moralnego oraz etyczna ocenę ludzkiego działania. Przejawia się to w tym, że współczesna cywilizacja czyni człowieka jednostkę lub społeczność - źródłem etycznej normy oraz miarą moralności. Tak rozumiana norma jest immanentna i zmienna, tak jak zmienna jest historia ludzkiego życia. Moralność obiektywna ustępuje etyce indywidualistycznej [sytuacyjnej], w ramach której każdy staje się dla siebie norma działania, co wyraża się w permisywizmie i liberalizmie moralnym. Człowiek

14 V. Possenti, Religia iżycie publiczne. Chrześcijaństwo $w$ dobie ponowożytnej, tł. T. Żeleźnik, Warszawa 2005, s. 39. Por. J. Zabielski, Życie jako wartość, „Archeus” 2(2001), s. $17-25$.

15 R. Dahrendorf, Fragmente eines neuen Liberalismus, Stuttgart 1987, s. 181.

${ }^{16}$ Por. V. Possenti, Religia i życie publiczne, dz. cyt., s. 39-40.

17 Jan Paweł II, Encyklika Evangelium vitae, 2. 
staje się kreatorem moralności, gdyż akt jego wolnej woli jest jedynym źródłem i gwarantem moralnej wartości ludzkiego działania. Tak pojmowana autonomia i prymat wolności jednostki nad dobrem, w życiu publicznym wyraża się w żądaniu, żeby prawo publiczne w możliwie największej mierze gwarantowało pluralizm moralny i wynikające z niego możliwości wyboru. W strukturze takiej autonomii szczególnie ważne są dwa czynniki: przyjęcie lub odrzucenie normatywności „zewnętrznej”, różnej od nadawanego sobie samemu prawa, oraz kwestia „drugiego", gdyż silna rewindykacja autonomii jednostki idzie w parze z zaciemnieniem pojęcia bycia drugim. Potwierdzeniem tego jest legalizacja aborcji czy eutanazji, uznawanej za prawo. W ten sposób ustawodawca - państwo zatraciło swoją najbardziej istotną cechę gwarancję neminem laedere. W prawie zaś np. aborcji płód jest uważany nie za kogoś należącego do my - do społeczności, i za kogo czuje się ona odpowiedzialna - ale jakby za res nullius, oddaną do swobodnej dyspozycji dorosłego, czego owa gwarancja nie obejmuje. Ta radykalna wersja autonomii ogranicza zasięg bycia drugim, rezerwując sobie prawo do decydowania, komu ten status przyznać. W ten sposób odwrócona została istota prawa i oznacza, że potestas, non veritas, facit legem [władza, nie prawda, stanowi prawo]. Innymi słowy, nie akt rozumu, lecz akt woli staje się źródłem prawa ${ }^{18}$. Konsekwencje tego rodzaju rozumowania widzimy w życiowych decyzjach i postawach wielu współczesnych ludzi. Pojawia się coraz więcej nurtów kulturowych, które przeciwstawiają się, a nawet wprowadzaja rozdział między wolnością a prawem, prowadząc do kreatywnej interpretacji sumienia. Tak pojmowane sumienie nie jest już zdolnością odczytywania prawa, którego człowiek „sam sobie nie nakłada”, lecz władzą tworzenia normy i arbitralnego orzekania o dobru i złu ludzkich czynów ${ }^{19}$.

\section{Podmiotowo-formalny wymiar analizowanego normatywu}

Przywołane tu niektóre charakterystyczne fenomeny moralnej kultury współczesności jawią się jako szczególne wyzwania w zakresie kształtowania nowego porządku świata. Odczytywanie tych wyzwań domaga się określenia podmiotu - adresata owych zobowiązań. Pierwszym i podstawowym

$18 \mathrm{~W}$ klasycznym rozumieniu, św. Tomasz definiuje prawo jako „rationis ordination ad bonum commune, ab eo qui curam communitatis habet promulgata”. STh I-II, q. 90, a. 4c. Por. V. Possenti, Religia i życie publiczne, dz. cyt., s. 98-102; J. Ratzinger, Die Bedeutung religiöser und sittlicher Werte in der pluralistischen Gesellschaft, „Concilium” [niem.] 21(1992), nr 6, s. 500-502; J. Clémence, L’homme source de la morale, "Nouvelle Revue Théologique” 113(1981), nr 3, s. 345-347.

19 Por. Sobór Watykański II, Konstytucja Gaudium et spes, 16; W. Arens, Tradition und Wertewandel. Versuch einer Orientierung in der Massengesellschaft, „Theologie und Glaube” 81(1991), nr 2, s. 165-167. 
podmiotem owego normatywu sa ludzie prezentujacy takie niebezpieczne myślenie i kształtujący odpowiednie postawy życiowe. Trudność i problematyczność doświadczenia przez nich tej powinności polega na tym, że praktycznie nie są oni zdolni do przeżycia owego normatywu, gdyż są przekonani o słuszności swoich koncepcji. Nie oznacza to jednak, że sam normatyw przeciwdziałania owym destrukcyjnym opcjom myślenia i działania osób za nie odpowiedzialnych ich nie dotyczy. Swiadomość jednak braku przeżycia takiej powinności wśród tych ludzi przenosi ten normatyw na ludzi świadomych niebezpieczeństwa wskazanych tu zjawisk. Adresatami tej powinności są wszyscy ludzie prawidłowo rozpoznający siebie oraz sens i cel swego bytowania. Wśród nich tą szczególną wspólnotą jawią się chrześcijanie, którzy otrzymali dar wiary, a tym samym obowiązek ewangelizacji. Papież Paweł VI podkreśla, że „nakaz ten i posłannictwo zobowiąuja tym bardziej w dobie wielkich i poważnych przemian w dzisiejszym świecie"20. Posłannictwo Kościoła i jego cele ukazuja, że podmiotem analizowanego normatywu jest zarówno cały Lud Boży, jak też poszczególne jego stany, wspólnoty i pojedyncze osoby. Ze względu na charakter formacyjny i możliwość oddziaływania praktycznego, szczególne miejsce i znaczenie w tym względzie posiada wspólnota naturalna - rodzina. „Ożywiony już we własnym wnętrzu «Kościół domowy» - podkreśla Jan Paweł II - jest powołany do tego, by był jaśniejącym znakiem obecności Chrystusa i Jego miłości także dla ludzi stojących «daleko», znakiem dla rodzin, które już nie żyją konsekwentnie wedle otrzymanej wiary: jest wezwany, ażeby "przykładem i świadectwem swoim» oświecał «tych, co szukają prawdy»"21.

Inną społecznościa, do których powinność kształtowania nowego świata jest szczególnie adresowana, sa szkoły wyższe i środowiska naukowe. Postawy bowiem naukowców i ich badania w dużym stopniu kształtują wizję porządku nowego świata, wywierając wpływ na myślenie oraz egzystencjalne postawy współczesnych i przyszłych pokoleń. Niestety, wiele współczesnych uniwersytetów i środowisk naukowo-badawczych coraz bardziej oddaje się nie poszukiwaniu prawdy, ale zasadzie posiadania. Uniwersytety europejskie, które były ośrodkami rozwoju i kultury, stopniowo przekształcają się w „zakłady” produkujące wiedzę będącą instrumentem dominowania nad światem. Wiele współczesnych szkół wyższych, urzeczonych skutecznością nauki, dało się uwieść, dostosowując się do cywilizacji technicznej. Ducha uniwersytetów często przenika dziś kategoria mieć, czyniąc z nich zakłady usługowe, w których profesorowie tworzą dla możnych coraz doskonalsze narzędzia opanowywania świata (praca badawcza), oraz produkuja coraz sprawniejszych konkwistadorów nie liczących się ani z natu-

20 Paweł VI, Adhortacja Apostolska Evangelii nuntiandi, 66. Por. J. Zabielski, Normatywny charakter współczesnej niewiary, art. cyt., s. 148-149.

21 Jan Paweł II, Adhortacja Apostolska Familiaris consortio, 54. Por. J. Fuchs, Der ethische Anruf, „Stimmen der Zeit” 121(1996), nr 7, s. 450-454. 
rą, ani z człowiekiem (praca dydaktyczna). Z uniwersytetów często wychodzą dziś ludzie niezdolni widzieć świat w jego prawdzie, lecz jedynie poprzez swoje interesy i sukcesy. W konsekwencji uniwersytety przestaja być sumieniem społeczeństw, gdyż nie troszczą się o poznawanie prawdy i kierowanie się nią w życiu. W środowiskach naukowo-badawczych zanika też troska o sprawiedliwość, o człowieka, a wzrasta zainteresowanie przedmiotami, którymi można dowoli się posługiwać i manipulować. W ten sposób uniwersytety tracą swój etos i stają się bezdomne, wpadając w wir pogoni za sukcesem i służąc tym, od których ich sukces zależy. Poddając się prymatowi techniki i posiadania nad poznaniem i byciem, traca swą wiarygodność, a ludzie zwracają się do uniwersyteckich środowisk nie po to, aby im wierzyć, ale żeby nimi się posługiwaćéc ${ }^{22}$. Świadomość takiej rzeczywistości wzmacnia powinność wobec społeczności akademickich, zwłaszcza w postaci wymogów rzetelności badań naukowych jako poznawania prawdy oraz kierowania się prawdą we wszelkich decyzjach życiowych.

W kontekście powinności naukowców i roli nauki w budowaniu porządku świata należy też mieć na uwadze rolę teologii i odpowiedzialność teologów. Jest to ważne z tego powodu, że treści teologiczne odnoszą się do podstawowych wymiarów ludzkiej egzystencji - sensu i celu bytowania człowieka w świecie. Współczesne zaś zobojętnienie na prawdy i zasady teologiczne oraz traktowanie ich z rezerwą i niedowierzaniem wymaga szczególnej wierności badawczej i merytorycznej wiarygodności przekazywanych treści. W tej sytuacji teolog winien zachować wyjątkowa wierność w rozpoznawaniu i interpretacji prawd objawionych. W trosce zaś o zachowanie merytorycznej wiarygodności teolog „musi sobie zdać sprawę, że gdy naucza, nie jest sam źródłem swego autorytetu, ale winien udostępnić i przekazywać zrozumienie wiary ostatecznie w imieniu Chrystusa i Kościoła”23. Dochowanie wierności tym wymogom sprawia, że współczesna teologia, zwłaszcza teologia moralna i jej nauczanie, „stoją dziś niewątpliwie wobec szczególnych trudności. Skoro moralność Kościoła musi mieć wymiar normatywny, nie można sprowadzać teologii moralnej do rzędu dyscypliny wiedzy ukształtowanej wyłącznie w kontekście tak zwanych nauk o człowieku. Podczas gdy te ostatnie zajmuja się moralnościa jako zjawiskiem historycznym i społecznym, teologia moralna [...] nie może być podporządkowana bez reszty wynikom obserwacji naukowej lub analizy fenomenologicznej"24.

Wyzwaniem współczesnej teologii w kontekście religijno-moralnego zobojętnienia jest też troska o to, żeby głoszone przez teologów prawdy i zasady były takie, którymi można żyć. Faktem natomiast jest, że nie zawsze

22 Por. P. Góralczyk, Uniwersytety w kontekście jednoczacej się Europy, „Wiadomości Kościelne Archidiecezji Białostockiej” 12(2003), nr 4, s. 170-171.

23 Jan Paweł II, Adhortacja Apostolska Pastores dabo vobis, 67.

24 Jan Paweł II, Encyklika Veritatis splendor, 111. Por. O. Höffe, Menschenwürde als ethisches Prinzip, w: „Gentechnik und Menschenwürde”, Köln 2002, s. 112-118. 
nauczanie teologiczne - zwłaszcza moralne - w społecznym odbiorze uchodzi za życiowo przydatne. Współczesny teolog działa więc na polu pełnym napięć: wierności Kościołowi i swemu sumieniu oraz powinności takiego przedstawienia teologicznej prawdy płynącej z wiary, aby obroniła się ona przed krytyką współczesności i dała odbiorcy wiarygodną i przekonująca orientację w codziennym życiu ${ }^{25}$. Należy przy tym pamiętać, że teologia należy do tych dziedzin nauki, która nie tylko przekazuje wiedzę, ale tė̇ a może przede wszystkim - wychowuje. Stąd też w nauczaniu teologii „chodzi nie tylko o epistemologiczny (filozoficzny) aspekt prawdy, lecz także o jej egzystencjalny, a więc moralnie znaczący aspekt: o prawdę w sensie wierności, na której można budować”26. Ten ostatni wymóg ma szczególne znaczenie w kontekście roli teologii w budowaniu nowego porządku świata. „Współczesna jednocząca się Europa - przypomina K. Lehmann - potrzebuje idei przewodnich, które pochodzą ze wspólnych przekonań, postaw, tradycji. Kościół nie tylko ich dostarcza, lecz stwarza motywację do ich zachowania. Podstawowe prawa bowiem, takie jak: sprawiedliwość, wolność, pokój, równość, solidarność i godność człowieka, bez zakotwiczenia w obszarze wiary zawieszone są niejako w próżni, a co gorsza, są także podatne na nadużycia ideologiczne"27.

Reasumując niniejsze refleksje, raz jeszcze należy uświadomić fakt, że myślenie i postawy wielu współczesnych nam ludzi budzą uzasadniony niepokój i stają się poważnym wyzwaniem współczesności. Człowiek wierzacy tę powinność przeżywać ma w kategorii normatywu wiary, choć wielokrotnie znajduje się na rozdrożu między wiernością sobie i Bogu a oczekiwaniami świata. Istotę owego normatywu oraz jego egzystencjalne znaczenie trafnie wyraził C. Cafarra: „Etyk, wierzacy w Chrystusa jest dziś kuszony coraz bardziej do zamknięcia się w zupełnym milczeniu. Jego głos każdego dnia coraz bardziej ryzykuje, że będzie źle rozumiany, co więcej, że będzie interpretowany dwuznacznie. Ma miejsce, jeśli się nie mylę, jedno z najbardziej podstępnych dążeń do "zniweczenia krzyża Chrystusa», jakie zna historia. Jest to dążenie do zasłonięcia istotnego środka «rdzenia» aktu odkupienia w etyce"28.

25 Por. J. Zabielski, Teologia i teolog $w$ świecie religijnego zobojętnienia, „Łomżyńskie Wiadomości Diecezjalne" 66(2004), nr 4, s. 174-183.

${ }^{26}$ J. Piegsa, Człowiek - istota moralna, t. 3, tł. R. Bigdon, G. Wenzel, Opole 2000, s. 13.

${ }^{27}$ K. Lehmann, Glauben bezeugen, Gesellschaft gestalten, Freiburg - Basel - Wien 1993, s. 38.

28 C. Cafarra, Etica generale della sessualità, Milano 1992, s. 115. 